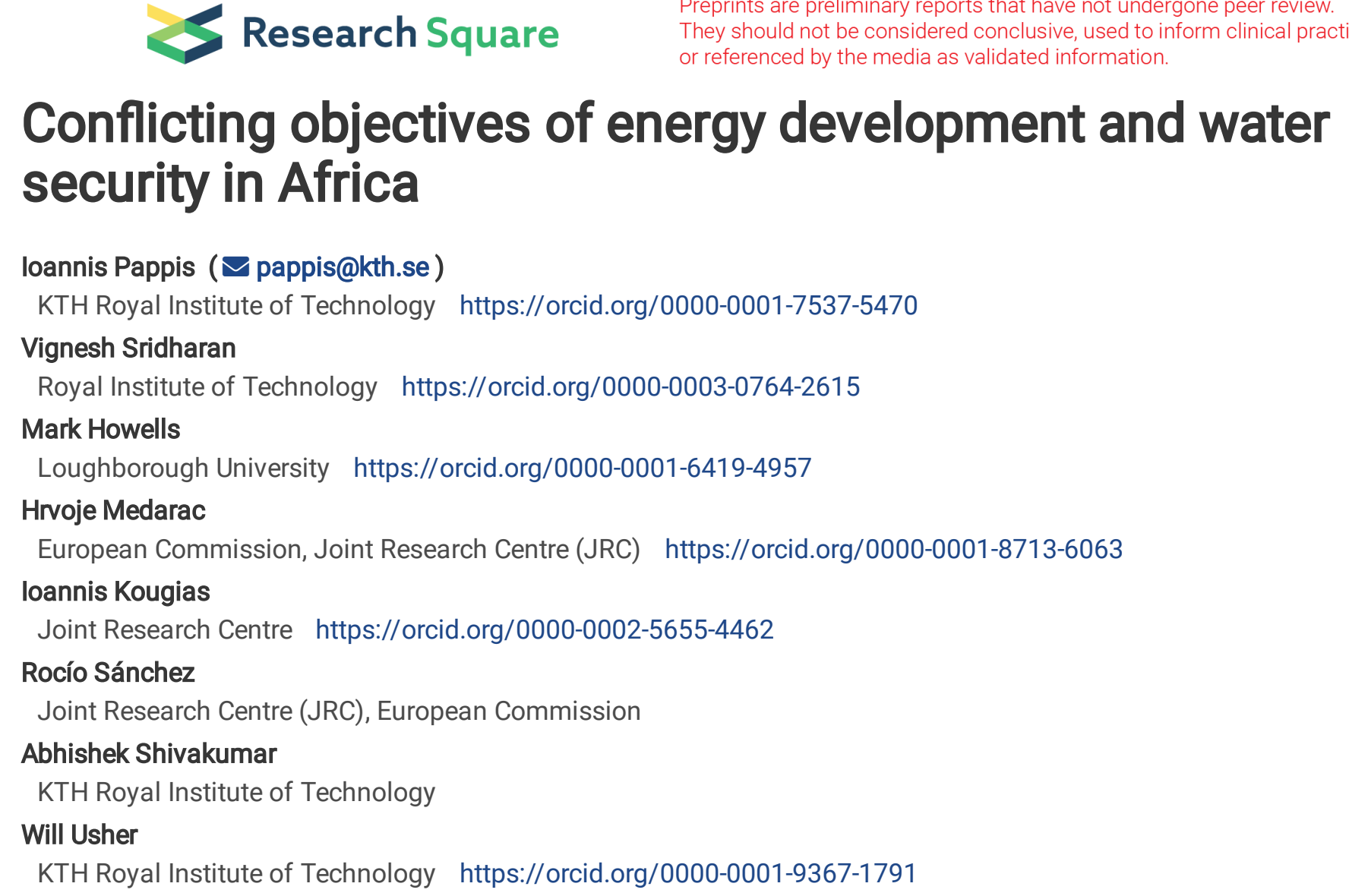

\section{Conflicting objectives of energy development and water security in Africa}

loannis Pappis ( $\square$ pappis@kth.se)

KTH Royal Institute of Technology https://orcid.org/0000-0001-7537-5470

\section{Vignesh Sridharan}

Royal Institute of Technology https://orcid.org/0000-0003-0764-2615

\section{Mark Howells}

Loughborough University https://orcid.org/0000-0001-6419-4957

\section{Hrvoje Medarac}

European Commission, Joint Research Centre (JRC) https://orcid.org/0000-0001-8713-6063

loannis Kougias

Joint Research Centre https://orcid.org/0000-0002-5655-4462

Rocío Sánchez

Joint Research Centre (JRC), European Commission

\section{Abhishek Shivakumar}

KTH Royal Institute of Technology

Will Usher

KTH Royal Institute of Technology https://orcid.org/0000-0001-9367-1791

\title{
Article
}

Keywords: energy development, water security, Africa, energy and water demands, low-carbon energy infrastructure

Posted Date: October 6th, 2020

DOI: https://doi.org/10.21203/rs.3.rs-84032/v1

License: (c) (i) This work is licensed under a Creative Commons Attribution 4.0 International License. Read Full License 


\section{Abstract}

Africa's economic and population growth prospects are likely to increase energy and water demands. This quantitative study shows that pathways towards decarbonization of the energy sector in Africa may lead to higher water withdrawals and consumption than expected. By 2065, investments in low-carbon energy infrastructure increase annual withdrawals from $1 \%$ $\left(2.0^{\circ} \mathrm{C}\right)$ to $2 \%\left(1.5^{\circ} \mathrm{C}\right)$ of total renewable water resources compared to $3 \%$ in the baseline scenario, despite lower final energy demands in the mitigation scenarios. Water consumption, in comparison to the baseline, increases by $282 \%\left(2.0^{\circ} \mathrm{C}\right)$ and $300 \%$ $\left(1.5^{\circ} \mathrm{C}\right)$ by 2065 , due to the high water-intensity of the low-carbon energy system. To meet the $1.5^{\circ} \mathrm{C}$ pathway, the energy sector requires higher water consumption overall and per unit of energy than other scenarios. These findings demonstrate the crucial role of integrated energy planning and water resources management if Africa is to achieve climate-compatible growth.

\section{Main}

Africa is facing severe water and energy challenges ${ }^{1}$. Population increase ${ }^{2}$, together with rapid urbanization ${ }^{3}$ and economic growth ${ }^{4}$, expect to increase water and energy needs in Africa. The interdependency of these two resources is important for Africa, which is vulnerable to climate change ${ }^{5}$. The continent hosts economically diverse countries (Fig. 1) with unevenly distributed energy and water resources (Supplementary Table 16).

Northern and Southern Africa are two of the most water-stressed regions in the continent (Fig. 1, Table 1). Overall, more than $300(\sim 25 \%)$ million people in Africa live in water-scarce regions ${ }^{3,6}$. Furthermore, the reliable supply of water is prone to disruptions in countries with low energy access ${ }^{7,8}$. The Central and Western regions contain the highest share of Total Renewable Water Resources (TRWR) ${ }^{9}, 53 \%$ and $25 \%$, respectively, while Northern Africa the lowest (1\%). This distribution makes an integrated energy-water approach fundamental to mitigate future challenges ${ }^{10}$.

Fuel processing and power plant operation require different amounts of water, indicated as water withdrawal (WW $)^{11}$ and water consumption (WC $)^{11}$. The reliable operation of thermal power plants depends on water availability ${ }^{12}$ and water temperature for cooling purposes. They comprise a high share (81\%) of installed electricity production capacity in Africa in $2016^{13}$, showing an increasing trend in the future ${ }^{13,14}$. Water is also required for household use and agricultural purposes ${ }^{15,16}$. Therefore, water availability is a crucial component of a nation's energy security together with energy resources ${ }^{3,17-22}$, geopolitical stance ${ }^{23}$ and energy strategy 24,25 . 
Table 1

List of African countries per power pool considered in the analysis (with the ISO 3166-1 alpha- $2^{28}$ country code in brackets).

\begin{tabular}{|lllll|}
\hline Central Africa (CAPP) & $\begin{array}{l}\text { Eastern Africa } \\
\text { (EAPP) }\end{array}$ & $\begin{array}{l}\text { Northern Africa } \\
\text { (NAPP) }\end{array}$ & $\begin{array}{l}\text { Southern Africa } \\
\text { (SAPP) }\end{array}$ & $\begin{array}{l}\text { Western Africa } \\
\text { (WAPP) }\end{array}$ \\
\hline Cameroon (CM) & Burundi (BI) & Algeria (DZ) & Angola (AO) & Benin (BJ) \\
\hline Central African Rep. (CF) & Djibouti (DJ) & Libya (LY) & Botswana (BW) & Burkina Faso (BF) \\
\hline Chad (TD) & Eritrea (ER) & Mauritania (MR) & Lesotho (LS) & Côte d'Ivoire (Cl) \\
\hline $\begin{array}{l}\text { Congo (CG) } \\
\begin{array}{l}\text { Democratic Rep. of Congo } \\
\text { (CD) }\end{array}\end{array}$ & Ethiopia (ET) & Morocco (MA) & Malawi (MW) & Gambia (GM) \\
\hline $\begin{array}{l}\text { Equatorial Guinea (GQ) } \\
\text { Gabon (GA) }\end{array}$ & Rwanda (RW) & Tunisia (TN) & Mozambique (MZ) & Ghana (GH) \\
\hline & Somalia (SO) & & Namibia (NA) & Guinea (GN) \\
\hline Sudan (SD) & & South Africa (ZA) & Guinea Bissau (GW) \\
\hline & South Sudan (SS) & & Swaziland (SZ) & Liberia (LR) \\
\hline Tanzania (TZ) & & Zambia (ZM) & Mali (ML) \\
\hline & Uganda (UG) & Zimbabwe (ZW) & Niger (NE) \\
\hline & Egypt (EG) & & Nigeria (NG) \\
\hline & & & Senegal (SN) \\
\hline
\end{tabular}

Computational models provide insights into the continent's future energy transformation, energy-water nexus linkages and climate change ${ }^{29}$. Flörke et al. ${ }^{30}$ conducted a global water use assessment using a water model in 177 countries for the period 1950-2010, demonstrating the relationship between water use and global-socioeconomic development. Lohrmann et al. ${ }^{31}$ estimated water demand for power production on a global, regional and country-level with mitigation strategies for the period 2015-2050 considering a high temporal and spatial resolution. Previous studies on estimating water requirements in the energy sector have focused on either a continental ${ }^{32-35}$ or regional $24,25,36,37$ level. Several studies have examined the effects of climate change upon the power sector, such as supply disruption ${ }^{25,38-40}$, increase in electricity prices ${ }^{41}$ and environmental impacts $^{42-45}$.

This study builds on past work by providing a quantitative multi-annual analysis estimating energy requirements, water withdrawal and consumption, carbon dioxide emissions, and costs of covering the future needs of the energy system in Africa including trade links among the African nations.

The energy systems of forty-eight African countries, with a focus on the power sector, are modeled individually using an opensource cost-optimization modeling framework (OSeMOSYS) ${ }^{46}$. We model three different scenarios for the period 2015-2065 ${ }^{47}$. The reference scenario assumes no change from national renewable energy policies after 2017. In two mitigation scenarios $\left(2.0^{\circ} \mathrm{C}, 1.5^{\circ} \mathrm{C}\right)$, the final energy demands are lower due to energy efficiency measures and the annual emission levels are constrained to the emission pathways compatible with the $2.0^{\circ} \mathrm{C}, 1.5^{\circ} \mathrm{C}$ scenarios ${ }^{48,49}$.

\section{Results}

Our results show that countries currently under high-risk of water scarcity are expected to further increase their water use in the future due to fossil fuel consumption, leading to a vicious cycle. Under mitigation scenarios $\left(2.0^{\circ} \mathrm{C}, 1.5^{\circ} \mathrm{C}\right)$, a reduction in demand in comparison to the reference scenario, coupled with the use of low-carbon technologies, leads to a decrease, but 
then an increase in water withdrawal and consumption, highlighting the role of nuclear, solar PV, hydropower and carbon capture with storage technologies (Supplementary Figure 2-7). Higher levels of electricity and gas trade are required to achieve lower emission limits, highlighting the role of transit countries and key net exporters. Nevertheless, it needs to be noted that higher levels of electricity exports in specific countries lead to higher levels of water withdrawal and consumption.

\section{Future energy sector water requirements in the African continent}

In the reference scenario, water withdrawals in Africa grew by almost eight times from 2015, reaching 159 billion cubic meters (bcm) in 2065. This increase corresponds to approximately 3\% (2065) of the Total Renewable Water Resources (TRWR $5,290 \mathrm{bcm}$ in 2015) in the continent ${ }^{27}$, assuming no changes in precipitation patterns due to climate change. This growth is mainly due to the penetration of high water-intensive technologies (coal, oil) and the increase in the hydropower share. Water consumption also increases by four times $(187 \mathrm{bcm})$ by 2065 .

In the reference scenario, in the Northern Africa power pool (NAPP) and Central African power pool (CAPP), there is an increase in water consumption despite the transformation of the future energy mix to a higher share of renewables and the use of less water-intensive thermal general technologies. This transformation is due to the rapid increase in energy demands. On the other hand, in the East African Power Pool (EAPP) and South African Power Pool (SAPP), the increase in water consumption is explained by the adoption of water-intensive technologies. NAPP, EAPP and the Western African power pool (WAPP) experience an increase in their water withdrawals by 2065 while SAPP and CAPP experience a decrease, $13 \%$ and $61 \%$, respectively. However, all power pools experience an increase in their water consumption ranging from 116\% (NAPP) to 1576\% (CAPP). Notably, countries with considerable hydropower potential (e.g., Angola, Cameroon, DRC, Ethiopia, Nigeria, Zambia) experience increased evaporative losses in the future (Supplementary Figure 47-49).

In the mitigation scenarios, overall water withdrawal also rise $\left(2.0^{\circ} \mathrm{C}, 52 \mathrm{bcm}\right.$, TRWR $\left.1 \%\right)\left(1.5^{\circ} \mathrm{C}, 85 \mathrm{bcm}\right.$, TRWR $\left.2 \%\right)$ but to a lesser extent compared to the reference scenario $\left(2.0^{\circ} \mathrm{C}, 67 \%\right),\left(1.5^{\circ} \mathrm{C}, 47 \%\right)$ by 2065 . Also, decarbonizing further, the energy sector leads to an increase in water consumption of $282 \%\left(2.0^{\circ} \mathrm{C}\right)$ and $300 \%\left(1.5^{\circ} \mathrm{C}\right)$ by 2065 , in Africa (Figure 2). These results support the message that pathways towards decarbonization of the energy sector in Africa may lead to higher water withdrawal and water consumption. This observation highlights the significant role of clean technologies with a low water footprint versus hydropower with integrated water resources management that secures water for other purposes (e.g., agriculture, municipal services). It is particularly relevant in NAPP and WAPP, which have set ambitious renewable energy targets. However, the projected nuclear investments in Egypt, Morocco, Chad, Guinea, Gabon, Uganda, Nigeria, Benin, Côte D Ivoire, Ghana, Senegal, Mali, increase water withdrawals in the above scenarios.

\section{The role of inter-regional trades, national mega-projects and transit countries}

Fossil-fuel reserves, renewable potential and water resources are unevenly distributed in Africa. The results show how trade among African countries could influence water resources management, decrease electricity generation costs and lower emission levels across the scenarios. The largest electricity net exporters by 2065 are Kenya, South Africa and Sudan, while the main net importers are Uganda, Burkina Faso and Mali. The high potential for renewables in the EAPP makes the region the largest net exporter of electricity. A notable finding of this study is the identification of some countries as transit-traders such as Egypt, Sudan, South Africa and Tanzania (Figure 3). Indicatively, under the reference scenario, Egypt imports 659TWh (94\%) of its cumulative electricity imports from Sudan. In parallel, Egypt exports approximately 1194TWh (96\%) of its cumulative electricity exports (2015-2065) to Asia. In parallel, 64TWh or 15\% of Sudan's total electricity exports are derived from imports of electricity generated in Ethiopia. Increased electricity trade enables optimized system operation and typically results in cheaper electricity costs and lower emission levels. However, for the exporting countries, there are consequences for their national water needs. Specifically, the potential implementation of the Grand Inga project in the Democratic Republic of Congo, together with trade links, could increase the electricity exports to neighboring countries and displace part of their fossilfuel based generation. Zimbabwe is one of the countries which undergo a transformation from net exporter in the reference 
scenario to a net importer in the decarbonization scenarios to reduce its fossil fuel-based generation capacity, importing on average 14 TWh of electricity annually.

These results highlight the importance of an enhanced electricity trading scheme on the continent to reduce greenhouse gas emissions and system costs. Nevertheless, this could come at the expense of increasing the water consumption in the main electricity exporter countries, particularly Ethiopia, Guinea, Liberia, Sudan, South Africa, putting them at risk of water shortages. However, countries such as Ghana, which increase their electricity net imports in all scenarios, experience a concurrent decrease in their water requirements. In short, investment decisions in large hydro-electricity generation projects cannot be separated from water resource management and electricity trade and require regional coordination across countries, tailored to the local geopolitical and topological realities.

Also, specific gas pipeline projects (e.g., West African, Trans-Saharan) could change certain countries (Algeria, Mozambique, Nigeria) to become energy hub exporters assisting their neighboring countries to transform their energy sector.

\section{Transformation of the energy system}

The evolution of the energy mix of a core group of fossil fuel resource-rich countries play an essential role in African greenhouse gas emissions. For example, South Africa and Lesotho extract most of the continent's final coal consumption. Nigeria and Egypt are large consumers of oil products. Algeria, South Africa, Nigeria, Egypt and the Democratic Republic of Congo will consume most of the continent's natural gas, in final energy terms. The analysis of how the final energy consumption evolves among the scenarios can be found in Supplementary Information.

In the reference scenario, the total African primary energy supply more than doubles compared to 2015 , reaching $1853 \mathrm{Mtoe}$ by 2065. While the share of fossil fuels increases over the years (64\%), renewables experience a gradual decrease, eventually reaching $36 \%$ of the total primary supply by 2065 (Figure 4). Without a carbon constraint, coal, as the cheapest source of electricity, constitutes most of the continent's primary energy supply, followed by oil and biomass. Nuclear power disappears from the electricity supply system by 2065 . The WAPP stands out as the most significant energy supplier (35\%) in Africa, followed by EAPP (28\%), SAPP (19\%), NAPP (11\%) and CAPP (7\%) in 2065 . WAPP is also the largest supplier (37\%) of fossil fuels and renewables (32\%) in the continent in 2065.

However, in the $2.0^{\circ} \mathrm{C}$ and $1.5^{\circ} \mathrm{C}$ scenarios, due to the relatively lower final energy demand, African countries increase their 2065 total primary energy supply by only $50 \%$ and $31 \%$, respectively, in comparison to 2015 . Moreover, the primary supply of

fossil fuels in those two scenarios declines dramatically throughout the years, reaching $27 \%$ and $8 \%$ by 2065 . On the contrary, renewables increase by $64 \%$ and $72 \%$, respectively, by 2065 (Figure 4).

As natural gas reserves are scattered among nations, the role of natural gas trade through pipelines and LNG terminals is key to decarbonize the African energy system. Countries with significant natural gas reserves, such as Algeria, Nigeria, or Mozambique, increase their natural gas exports significantly to reduce the consumption of more polluting fossil fuels in the continent. In particular, Mozambique increases its gas exports to South Africa for replacing coal in the power sector with natural gas.

Under the mitigation scenarios, natural gas supply to Europe through the Northern African countries gradually declines, which is in line with Europe's aim to become a climate-neutral continent by 2050 . The Western African power pool and specifically Nigeria, will be the leading natural gas supplier in the African continent. Several coastal countries (Côte D Ivoire, Ghana, Morocco, Sudan, Senegal, Tunisia, Tanzania and South Africa) increase their LNG imports. This increase in imports leads to lower emission limits by replacing the above countries' fossil fuel capacity in the power sector as well as decreasing their water requirements.

\section{Evolution of the electricity supply sector}


In the reference scenario, the overall generation capacity in Africa rises ten-fold from 181GW (2015) to 1863GW (2065). The share of renewables increases from 19\% (2015) to 78\% (2065), while the percentage of thermoelectric capacity decreases from $82 \%$ (2015) to $22 \%$ (2065). Hydropower was the dominant renewable source in 2015. However, as the costs of renewable (solar, wind) technologies are declining throughout the years, solar photovoltaic (PV) technologies represent most of the continent's installed capacity by 2065. In the decarbonization scenarios, the percentage of renewables reach even higher figures $86 \%\left(2.0^{\circ} \mathrm{C}\right)$ and $87 \%\left(1.5^{\circ} \mathrm{C}\right)$ in 2065 and resulting in generation capacities of $1843 \mathrm{GW}\left(2.0^{\circ} \mathrm{C}\right)$ and $1833 \mathrm{GW}\left(1.5^{\circ} \mathrm{C}\right)$.

In the reference scenario, CAPP is electrified almost exclusively by renewables (94\% of installed capacity) in 2065 . At the same time, EAPP hosts most of the continent's renewable installed capacity (427GW) and NAPP experiences the highest increase (46 fold) in all scenarios. As expected, CAPP becomes the leading hydropower producer due to the Democratic Republic of Congo and EAPP (Sudan, Uganda) continues to invest in hydropower. Concentrated Solar Power (CSP) technologies are limited to NAPP (Morocco) and EAPP (Egypt) and geothermal to EAPP (Kenya, Ethiopia). In mitigation scenarios, to achieve the emission targets, carbon capture and storage (CCS) technologies and nuclear power plants are required along with the replacement of coal-based power plants by natural gas.

Nevertheless, to encourage decarbonization of the energy sector, the technological maturity of CCS technologies needs to be considered along with the feasibility of nuclear energy in the African context. Socio-economic concerns of nuclear power exceed the scope of this analysis ${ }^{50}$. In decarbonization scenarios, WAPP (Nigeria, Ghana), Egypt and Morocco present most of the continent's nuclear capacity in the future, mainly replacing thermal capacity. In the same scenarios, SAPP (Angola, South Africa, Zambia, Zimbabwe) invests significantly in biomass with CCS technologies while Egypt invests in natural gas with CCS.

Our results show that to decarbonize the energy sector, the gas-fired power generation technologies, along with the penetration of renewables, CCS and nuclear technologies, replace coal-based power generation. In the reference scenario, electricity generation in Africa increases from 64Mtoe (2015) to 510Mtoe (2065). Renewables gradually penetrate the electricity mix reaching $57 \%$ (2065) from $18 \%$ in 2015 and $75 \%$ in both the $2.0^{\circ} \mathrm{C}$ and $1.5^{\circ} \mathrm{C}$ scenarios. Solar PV technologies followed by hydropower are the dominant power generation renewables in the future. In the reference scenario, coal-based power generation is the primary thermal power source in the long-term instead of natural gas in the decarbonization scenarios where thermoelectric generation is lower than in the reference scenario $(45 \%$ in 2065$)$, specifically $34 \%\left(2.0^{\circ} \mathrm{C}\right)$ and $31 \%\left(1.5^{\circ} \mathrm{C}\right)$ by 2065.

Also, technologies combining CCS constitute $9 \%\left(2.0^{\circ} \mathrm{C}\right)$ and $8 \%\left(1.5^{\circ} \mathrm{C}\right)$ of the total electricity generation by 2065 . An insight among the scenarios is that the coal-based power generation regions, SAPP and WAPP, replace their generation significantly by wind and solar in the first case while in the second case with natural gas and nuclear.

\section{Finance}

In the reference scenario, the total system costs associated with the energy sector in Africa are estimated at USD 201524,520 trillion. Under the mitigation scenarios, the total costs are lower by $29 \%\left(2.0^{\circ} \mathrm{C}\right)$ and $54 \%\left(1.5^{\circ} \mathrm{C}\right)$ compared to the reference scenario, for the period 2015-2065. In the mitigation scenarios, the penetration of renewable technologies leads to fuel supply savings of $32 \%\left(2.0^{\circ} \mathrm{C}\right)$ and $53 \%\left(1.5^{\circ} \mathrm{C}\right)$ compared to the reference scenario (Figure 5$)$. As expected, mitigation scenarios are capital-intensive and the capital investments in the power sector are higher by approximately $9 \%\left(2.0^{\circ} \mathrm{C}\right)$ and $19 \%\left(1.5^{\circ} \mathrm{C}\right)$ compared to the reference scenario (Figure 5). Despite that, the significantly lower operating expenses, show that decarbonization options, which include energy efficiency measures, are beyond any doubt the cost-efficient pathways. This indicates that increasing the ambition of climate targets results in lower cumulative costs. All scenarios assume universal access to clean energy by 2065 , hence the high investment projections in $2030-2065$.

Developing strategies for the African continent should, therefore, prioritize sustainable technologies, demand-side management and set ambitious targets. This also applies to oil-producing countries of the continent (e.g., Algeria, Tunisia) 
since they are expected to profit from electricity trading leading to savings on their total fuel costs by $48 \%\left(2.0^{\circ} \mathrm{C}\right) / 46 \%$ $\left(1.5^{\circ} \mathrm{C}\right)$ and power system costs by $28 \%\left(2.0^{\circ} \mathrm{C}\right) / 7 \%\left(2.0^{\circ} \mathrm{C}\right)$ compared to the reference scenario, improving in parallel their water productivity by approximately $50 \%$.

\section{Discussion}

The results offer insights into how the policy agenda on sustainability and economic growth could be strengthened at the global and continental level by considering the interdependency of energy and water sectors.

Previous studies have highlighted the role of low carbon electricity to meet climate change targets. Our results indicate that to meet the $1.5^{\circ} \mathrm{C}$ pathway, the energy sector requires higher water consumption overall and per unit of final energy, so proper water resource management is essential. The reason behind this is the penetration of nuclear and hydropower technologies. Aside from increasing water consumption, hydropower creates new opportunities as it is an enabling infrastructure for effective water resources management. The additional services (water storage, flood risk mitigation) may counterbalance the associated withdrawals.

The results highlight the role of electricity and gas trading schemes among the African nations and how a trading scheme could help achieve more ambitious emission targets and lower system costs. Findings also reveal the future role of some countries as key net exporters and transit hubs. Besides, the possible implementation of mega-projects (Grand Inga Dam) could further boost trading and supply with low carbon electricity on the continent. In any case, integrated and transboundary water resource management is a sine qua non of Africa's sustainable development and needs to be harmonized with energy investments.

Findings show the different strategies between countries based on their indigenous energy resources while increasing electricity trade and substituting fossil-fuel-based power generation to reduce generation costs. The integrated model highlights the linkage between energy and water security. As nations invest in new power plants to increase electricity exports, this could come at the cost of their available water resources and even trigger geopolitical conflicts. The increased ambition of African energy and climate targets would probably reduce energy exports to non-African countries, negatively affecting their energy security and limit potential trade options. This would, however, be outweighed by the significantly lower system costs of transforming Africa's energy sector following ambitious climate targets. LNG imports through coastal countries also play an essential part in decarbonizing the energy system by replacing coal-based power generation plants.

Also, countries such as Egypt, Algeria, Morocco, South Africa and Angola, are expected to construct significant thermal generation capacity on the coast, using seawater for cooling as the water is freely available. Thus the associated risks with climate change (e.g., sea-level rise) need to be considered.

If countries were to continue energy exports at the current level, the effects upon water withdrawals demonstrated in these results would be exacerbated. In the decarbonization scenarios, exports of primary fossil fuel resources decrease at a level commensurate with global action on climate change. Large exporting countries, such as Algeria, Nigeria, South Africa, need to consider the trade-offs between the revenues of energy exports with other countries, the local consumption that will boost economic growth and increase water requirements and energy security.

It is important to understand the linkages as well as the individual challenges of energy and water to develop effective strategies towards sustainable development, especially under climate change. Global-national-regional ${ }^{50,51}$ policies, along with future adoption of technologies, declining costs of renewables, oil price fluctuations and new business models, should be considered in an integrated manner to address the challenges indicated in the United Nations Sustainable Development Goals (SDGs) in particular SDG6, SDG7, SDG13 ${ }^{8}$. Also, climate change and sustainable development governance should be better integrated to maximize the effectiveness of action in both domains ${ }^{52}$. 
The continental-scale insights could inform the National Determined Contributions targets (to be reviewed in 2020) ${ }^{50}$, by demonstrating the broader African context of national greenhouse gas emission targets. National and governmental institutions, as well as universities involved in capacity building activities, could benefit from this open-source study since the provided datasets could strengthen the capacity for developing others and extending existing energy systems models.

There is scope for further work based on the results of this study. Combining agricultural and municipal water withdrawals ${ }^{27}$ for each African nation with our results would show the impact of the scenarios upon levels of water-stress ${ }^{26}$.

Linking a water-systems model to the energy-system model of this study would provide insights into the resilience of the African continent in terms of water and energy under climate change. Hydrological modeling of each of the planned dams would provide more accurate quantification of dam productivity and impacts. Broader social and environmental effects of hydropower and nuclear, which are outside the scope of this study, should be further examined at a power pool or regional scale along with mitigation strategies to understand the implications of those technologies better. Battery storage for solar PV and pumped hydropower storage are only implicitly modeled due to the macroscopic nature of the study that focuses on Africa's urgent need for access to energy and water and computational constraints. Better data and spatial techniques could help identify and allocate the different cooling technologies to future thermal power plants. Also, incorporating countryspecific reserve margins rather than using an average, the power sector projections would improve the representation of national energy systems. Finally, although included in the scenario analysis, some significant uncertainties around technology costs, fuel prices and future energy demands are not yet systematically explored, which would provide further evidence into the robustness of these results.

\section{Methods}

We developed a model to evaluate energy supply and water requirements to cover the energy needs of the African continent during the period 2015-2065. The model was developed using the open-source modeling system for long-term energy planning OSeMOSYS ${ }^{46}$. The objective function is to minimize total energy system costs, rather than, for example, co-optimize the energy and water sectors. Other energy resources were also included in the model except for adding the water analysis, and the dataset was updated based on the latest available information. The OSeMOSYS model developed to conduct the study "Energy projections for African countries" 47 , itself extended from the Electricity Model Base for Africa (TEMBA) ${ }^{53}$, was further extended, including exports for all fuels and water loss due to evaporation in hydropower plants. Furthermore, the latest available data on the energy system of Africa was also updated considering national energy policies. In the following subsections, the detailed methodology followed to develop the model is described.

\section{Energy-water model development}

The energy model was developed using the open-source cost-optimization energy system modeling framework (OSeMOSYS) ${ }^{46}$ for medium to long term energy planning. OSeMOSYS is a bottom-up modelling framework that uses linear optimization techniques to satisfy an exogenously defined energy demand. OSeMOSYS has been employed in the scientific literature to provide insights on possible transformation pathways of large energy systems and their impacts on the economy, the society and the environment ${ }^{54}$. The open-source method of the study assists in overcoming the lack of transparency needed to address future long-term decarbonization trajectories ${ }^{55}$.

The electricity supply system, including a simple representation of other energy sources (heavy fuel oil, light fuel oil, gas, coal, biofuel \& waste), of forty-eight (48) African countries was modeled individually and linked via electricity interconnectors and natural gas pipelines to shape the African model. Countries were then associated with the following regional power pools ${ }^{56}$ : Central Africa (CAPP), Eastern Africa (EAPP), Northern Africa (NAPP), Southern Africa (SAPP) and Western Africa (WAPP) to identify trades. The North African Power Pool (NAPP), as it is reported here, is officially called the Maghreb Electricity Committee, or COMELEC. The analysis provided results on a continental-regional-country level at an annual temporal 
resolution for the period 2015-2065. Country specific hourly electricity generation profiles and seasonality of the electricity load were considered in the analysis.

Starting from the supply, fuel supply technologies were categorized per country in extraction and imports, associated with fuel prices distinguishing between inland and coastal, as well as conversion technologies (Liquified natural gas, gas regasification plant, refineries); electricity and natural gas interconnection projects among African countries, as well as with other continents; and country-specific energy resources (renewable potential, fossil fuel reserves).

Moving to power generation, centralized and decentralized (off-grid) technologies were modeled, taking into consideration techno-economic parameters. New technologies such as carbon capture and storage (CCS) were also represented. Countryspecific capacity factors (wind, solar) were introduced to capture better the granularity of electricity generation as well as transmission and distribution losses.

Lastly, at the end-user level, country-specific final energy demands (electricity, biofuel and waste, coal, gas, heavy fuel oil, light fuel oil) were captured and modified accordingly in each of the scenarios (Supplementary Table 1-15). The final energy demands and fuel exports (coal, crude oil, oil products, biofuels and waste) are exogenous parameters to the model. Emission factors were assigned per type of fuel, while the emission limits in decarbonization scenarios were placed on a regional and not country level.

\section{Power plant data}

Power plant data was obtained from the World Electric Power Plants database ${ }^{13}$ and validated with online sources ${ }^{57,58}$ and national master plans. In total, 5,300 power plants were examined, of which 3,646 power plants are thermal power plants. The power generation technologies are categorized into centralized and decentralized, per type of technology and separated in fossil fuel and nuclear, renewable and carbon capture and storage (Supplementary Table 39). Techno-economic parameters were assigned to the technologies (Supplementary Table 17-20). In addition, the power plants are categorized as old (existing capacity until 2014), or new with efficiency and cost improvements.

\section{Water demand}

The Total annual Renewable Water Resources (TRWR) in Africa is the theoretical maximum annual volume of water resources available ${ }^{9}$, approximately 5,290 billion cubic meters ${ }^{27}$. Water withdrawal is the total volume removed from a water source such as a lake or river. In contrast, water consumption refers to the portion of the withdrawn water that is permanently removed and not returned to its source ${ }^{11}$.

To estimate the water withdrawal and consumption per type of technology and consequently the water demand by a country, we considered different cooling types: dry cooling (AIR), natural and mechanical draft tower (MDT/NDT), once-through cooling tower with freshwater (OTF) and once through cooling tower with salt water (OTS) per type of technology (power generation). Based on the identified cooling type, specific water factors were assigned (Supplementary Table 22). The cooling type of the existing power plants was obtained from the World Electric Power Plants database ${ }^{13}$ and completed with visual estimations based on satellite images using Google Earth. The new power plants were assumed to have the same cooling type as the majority of the existing power plants in the corresponding country for each fuel type. However, in cases where the available data for the current technologies were insufficient to identify their cooling type in the relevant countries, we used weighted averages. Water factors have also been applied to estimate water use for fuel extraction and processing

(Supplementary Table 23). The following equations ${ }^{59}$ were used to obtain water use of fuel production (1) and water withdrawal and consumption for power plant operation (2) for each country:

$$
\begin{aligned}
& W F P\left(m^{3}\right)=\text { Fuel produced }(M W h f) * \text { Fuel water factor }\left(\frac{m^{3}}{M W h f}\right)(1) \\
& W O P\left(m^{3}\right)=\sum_{k}^{n} \text { Electricity generated } k_{k} * \text { Cooling type water factor }\left(\frac{m^{3}}{M W h}\right)(2)
\end{aligned}
$$


Where WFP is the water use for fuel production and processing, WOP is the water use for power plant operation and $\mathrm{n}$ the number of power plants in each country.

Future water consumption allocated to hydro-electricity was also addressed based on a previous study that analyses the water loss due to evaporation in the biggest 158 hydropower reservoirs in Africa in $2016^{59}$. The corresponding hydropower plants in these reservoirs represent $95 \%$ of the total hydropower installed capacity in the continent. These country-specific water factors were applied to the hydro-electricity projections for the different scenarios.

The water use for biomass extraction was not included in the study.

\section{Decarbonization scenarios}

To explore plausible future developments of the African energy sector, we developed three scenarios. The reference scenario assumes that there is no change from the national renewable energy policies after 2017. In the two mitigation scenarios $\left(2.0^{\circ} \mathrm{C}, 1.5^{\circ} \mathrm{C}\right)$, the fuel demands of each African country are derived from the JRC GECO 2018 report $^{48}$ and disaggregated based on socio-economic factors $\left(\mathrm{GDP}^{48}\right.$, population $\left.{ }^{2}\right)$. In the reference scenario, the carbon dioxide emissions increase by approximately three times, compared with 2015 levels, reaching to 3,466 Mt of CO2 by 2065. The annual emission levels are constrained to the emission pathways compatible with the $2.0^{\circ} \mathrm{C}, 1.5^{\circ} \mathrm{C}$ scenarios ${ }^{48,49}$. Carbon removal technologies were also introduced in these two scenarios.

Under the $2.0^{\circ} \mathrm{C}$ and $1.5^{\circ} \mathrm{C}$ scenarios, we assume the implementation of energy efficiency policies and a significant reduction in fossil fuel consumption (Fig. 4). As a consequence, the total final energy demand increases by only $79 \%$ and $49 \%$, respectively, by 2065 over 2015 levels.

Projections for the energy transition of each country were calculated based on historical energy balances ${ }^{60,61}$, future GDP ${ }^{48}$ and population ${ }^{2}$ estimates and calibrated following the report of Keramidas et al. ${ }^{48}$, for the period 2015-2065. The national renewable targets of each country until 2017 were included in the model Supplementary Table 29. Three scenarios were examined in this analysis: reference, $2.0^{\circ} \mathrm{C}$ and $1.5^{\circ} \mathrm{C}$. The fuel demand, $\mathrm{CO}_{2}$ mitigation level, penetration of new technologies (CCS) and adoption of new policies are some factors that diversify the development of the scenarios. The different future fuel mix among the scenarios was analyzed outside of the model. The mitigation scenarios $\left(2.0^{\circ} \mathrm{C}, 1.5^{\circ} \mathrm{C}\right)$ assume future emission reduction targets aiming at a global mean temperature increase of $2.0^{\circ} \mathrm{C}$ with a $67 \%$ probability ${ }^{48,49}$ and $1.5^{\circ} \mathrm{C}$ increase with a $50 \%$ probability by 2100 . The scenarios are estimates and provide future pathways based on given assumptions and should not be considered as predictions.

\section{Data availability}

The dataset used to develop the model can be found in the Github repository. The detailed model results by country, power pool and continental level for the different scenarios can be found in the JRC Data Catalogue repository under the WEFE collection.

\section{Code availability}

The osemosys code used to develop the model for Africa can be found on a Github repository.

\section{Declarations}

\section{Competing interests}

The authors declare no competing interests.

\section{Additional information}

Publisher's note Springer Nature remains neutral with regard to jurisdictional claims in published maps and institutional affiliations. 


\section{References}

1. International Energy Agency. Water-Energy Nexus. https://www.iea.org/reports/water-energy-nexus (2017).

2. United Nations, Department of Economic and Social Affairs, Population Division (2017). World Population Prospects Population Division - United Nations. https://population.un.org/wpp/.

3. The World Bank. World Bank Open Data | Data. https://data.worldbank.org/ (2018).

4. International Monetary Fund. Regional Economic Outlook: Sub-Saharan Africa. (2019).

5. Nangombe, S. et al. Record-breaking climate extremes in Africa under stabilized $1.5^{\circ} \mathrm{C}$ and $2{ }^{\circ} \mathrm{C}$ global warming scenarios. Nat. Clim. Change 8, 375-380 (2018).

6. United Nations Environment Programme. Africa Environment Outlook: Past, Present and Future Perspectives. (Earthprint for and, 2002).

7. International Energy Agency. World Energy Outlook 2018. (2018).

8. Nerini, F. F. et al. Mapping synergies and trade-offs between energy and the Sustainable Development Goals. Nat. Energy 3, 10 (2018).

9. Food and Agriculture Organization. 2. CONCEPTS AND DEFINITIONS. http://www.fao.org/3/y4473e/y4473e06.htm.

10. United Nations Development Programme (UNDP). 2013 Human Development Report. http://hdr.undp.org/en/reports/global/hdr2013/download/ (2013).

11. GRACE Communications Foundation. Water Use, Withdrawal and Consumption. Water Footprint Calculator https://www.watercalculator.org/footprint/water-use-withdrawal-consumption/.

12. FAO. 2. WATER SOURCES AND WATER AVAILABILITY. http://www.fao.org/3/U5835E/u5835e03.htm.

13. Platts. Platts- World Electric Power Plants Database. World Electric Power Plants Database http://www.platts.com/Products/worldelectricpowerplantsdatabase (2016).

14. African countries plan to build dozens of coal-fired power stations. The Economist.

15. United Nations. Sustainable Development Goals .. Sustainable Development Knowledge Platform. https://sustainabledevelopment.un.org/?menu=1300 (2015).

16. Szabó, S., Moner-Girona, M., Kougias, I., Bailis, R. \& Bódis, K. Identification of advantageous electricity generation options in sub-Saharan Africa integrating existing resources. Nat. Energy 1, 1-8 (2016).

17. U.S. Energy Information Administration (EIA). Egypt. (2018).

18. Hermann, S., Miketa, A. \& Fichaux, N. Estimating the Renewable Energy Potential in Africa GIS-based approach. (2014)

19. International Renewable Energy Agency, Abu Dhabi. Planning and prospects for renewable power: West Africa. (2018).

20. Miketa, A. \& Merven, B. Southern African Power Pool: Planning and Prospects for Renewable Energy. https://www.irena.org/publications/2013/Jun/Southern-African-Power-Pool-Planning-andProspects-for-RenewableEnergy (2013).

21. Ndhlukula, K., Radojicic, T., Mangwengwende, S., Radojičić, T. \& Mangwengwende, S. Africa Clean Energy Corridor: Analysis of Infrastructure for Renewable Power in Eastern and Southern Africa. 80 (2015).

22. United Nations Industrial Development Organization. World Small Hydropower Development Report 2016. (2016).

23. Stokstad, E. Power play on the Nile. Science 351, 904-907 (2016).

24. Medarac, H., Magagna, D. \& Hidalgo Gonzalez, I. Projected fresh water use from the European energy sector. https://publications.jrc.ec.europa.eu/repository/handle/111111111/54145 (2018) doi:10.2760/30414 (online).

25. Conway, D., Dalin, C., Landman, W. A. \& Osborn, T. J. Hydropower plans in eastern and southern Africa increase risk of concurrent climate-related electricity supply disruption. Nat. Energy 2, 946-953 (2017).

26. FAO. Progress on level of water stress - Global baseline for SDG 6 Indicator 6.4.2 2018. (2018).

27. FAO. AQUASTAT database. http://www.fao.org/nr/water/aquastat/data/query/results.html (2017).

28. International Organization for Standardization. Online Browsing Platform (OBP). https://www.iso.org/obp/ui/\#search.

Page $11 / 18$ 
29. Calder, M. et al. Computational modelling for decision-making: where, why, what, who and how. R. Soc. Open Sci. 5, 172096.

30. Flörke, M. et al. Domestic and industrial water uses of the past 60 years as a mirror of socio-economic development: A global simulation study. Glob. Environ. Change 23, 144-156 (2013).

31. Lohrmann, A., Farfan, J., Caldera, U., Lohrmann, C. \& Breyer, C. Global scenarios for significant water use reduction in thermal power plants based on cooling water demand estimation using satellite imagery. Nat. Energy (2019) doi:10.1038/s41560-019-0501-4.

32. Tramberend, S. et al. BUILDING GLOBAL WATER USE SCENARIOS. 65 http://pure.iiasa.ac.at/id/eprint/11675/1/IR-15014.pdf (2015).

33. Spang, E. S., Moomaw, W. R., Gallagher, K. S., Kirshen, P. H. \& Marks, D. H. The water consumption of energy production: an international comparison. Environ. Res. Lett. 9, 105002 (2014).

34. Vassolo, S. \& Döll, P. Global-scale gridded estimates of thermoelectric power and manufacturing water use. Water Resour. Res. 41, (2005).

35. Larsen, M. A. D. \& Drews, M. Water use in electricity generation for water-energy nexus analyses: The European case. Sci. Total Environ. 651, 2044-2058 (2019).

36. Siddiqi, A. \& Anadon, L. D. The water-energy nexus in Middle East and North Africa. Energy Policy 39, 4529-4540 (2011).

37. De Felice, M., Gonzalez Aparicio, I., Huld, T., Busch, S. \& Ignacio Hidalgo Gonzalez. Analysis of the water-power nexus in the West African Power Pool. https://ec.europa.eu/jrc/en/publication/analysis-water-power-nexus-west-african-powerpool (2018).

38. Röhrkasten, S., Schäuble, D. \& Helgenberger, S. Secure and Sustainable Energy in a Water-Constrained World. https://www.iass-potsdam.de/en/output/publications/2016/secure-and-sustainable-energy-water-constrained-world (2016).

39. Farquharson, D., Jaramillo, P. \& Samaras, C. Sustainability implications of electricity outages in sub-Saharan Africa. Nat. Sustain. 1, 589-597 (2018).

40. Behrens, P., van Vliet, M. T. H., Nanninga, T., Walsh, B. \& Rodrigues, J. F. D. Climate change and the vulnerability of electricity generation to water stress in the European Union. Nat. Energy 2, (2017).

41. Sridharan, V. et al. Vulnerability of Uganda's Electricity Sector to Climate Change: An Integrated Systems Analysis. in Handbook of Climate Change Resilience (ed. Leal Filho, W.) 1-30 (Springer International Publishing, 2018). doi:10.1007/978-3-319-71025-9_45-1.

42. Lucena, A. F. P. et al. Climate policy scenarios in Brazil: A multi-model comparison for energy. Energy Econ. 56, 564-574 (2016).

43. Olhoff, A., Ansuategi, A., Boulahya, M. S. \& Shuting, Y. Climate Impacts on Energy Systems: Key Issues for Energy Sector Adaptation. (ESMAP, World Bank, 2011).

44. Valérie Masson-Delmotte \& P. Zhai, H.-O. Pörtner, D. Roberts, J. Skea, P.R. Shukla, A. Pirani, W. Moufouma-Okia, C. Péan, R. Pidcock, S. Connors, J.B.R. Matthews, Y. Chen, X. Zhou, M.I. Gomis, E. Lonnoy, T. Maycock, M. Tignor, and T. Waterfield. IPCC, 2018: Global Warming of $1.5^{\circ} \mathrm{C}$.An IPCC Special Report on the impacts of global warming of $1.5^{\circ} \mathrm{C}$ above preindustrial levels and related global greenhouse gas emission pathways, in the context of strengthening the global response to the threat of climate change, sustainable development, and efforts to eradicate poverty. $32 \mathrm{pp}$.

45. van Vliet, M. T. H., Wiberg, D., Leduc, S. \& Riahi, K. Power-generation system vulnerability and adaptation to changes in climate and water resources. Nat. Clim. Change 6, 375-380 (2016).

46. Howells, M. et al. OSeMOSYS: The Open Source Energy Modeling System: An introduction to its ethos, structure and development. Energy Policy 39, 5850-5870 (2011).

47. Pappis, I. et al. Energy projections for African countries. https://op.europa.eu/publication/manifestation_identifier/PUB_KJNA29904ENN (2019). 
48. Keramidas, K. et al. Global energy and climate outlook 2018 sectoral mitigation options towards a low-emissions economy: global context to the EU strategy for long-term greenhouse gas emissions reduction. (2018).

49. van Vuuren, D. P. et al. RCP2.6: exploring the possibility to keep global mean temperature increase below $2^{\circ} \mathrm{C}$. Clim. Change 109, 95 (2011).

50. United Nations Climate Change. Nationally Determined Contributions (NDCs) | UNFCCC. https://unfccc.int/process-andmeetings/the-paris-agreement/nationally-determined-contributions-ndcs.

51. African Union \& Commission. Agenda 2063: the Africa we want. (2015).

52. Fuso Nerini, F. et al. Connecting climate action with other Sustainable Development Goals. Nat. Sustain. 2, 674-680 (2019).

53. Taliotis, C. et al. An indicative analysis of investment opportunities in the African electricity supply sector - Using TEMBA (The Electricity Model Base for Africa). Energy Sustain. Dev. 31, 50-66 (2016).

54. Gardumi, F. et al. From the development of an open-source energy modelling tool to its application and the creation of communities of practice: The example of OSeMOSYS. Energy Strategy Rev. 20, 209-228 (2018).

55. Pfenninger, S. Energy scientists must show their workings. Nature 542, 393-393 (2017).

56. Medinilla, A., Byiers, B. \& Karaki, K. African power pools Regional Energy, National Power. (2019).

57. REN21. REN21 Building the sustainable energy future with renewable energy. REN21 https://www.ren21.net/.

58. IRENA. Renewable Energy Statistics 2019. 398 https://www.irena.org/-/media/Files/IRENA/Agency/Publication/2019/Jul/IRENA_Renewable_energy_statistics_2019.pdf (2019).

59. Gonzalez Sanchez, R. et al. Freshwater use of the energy sector in Africa. Appl. Energy 270, 115171 (2020).

60. OECD. World energy balances. https://www.oecd-ilibrary.org/energy/data/iea-world-energy-statistics-and-balances/worldenergy-balances_data-00512-en.

61. United Nations Department for Economic and Social Affairs Statistics Division. UNSD - Energy Balances 2016. https://unstats.un.org/unsd/energystats/pubs/balance/ (2018).

\section{Figures}




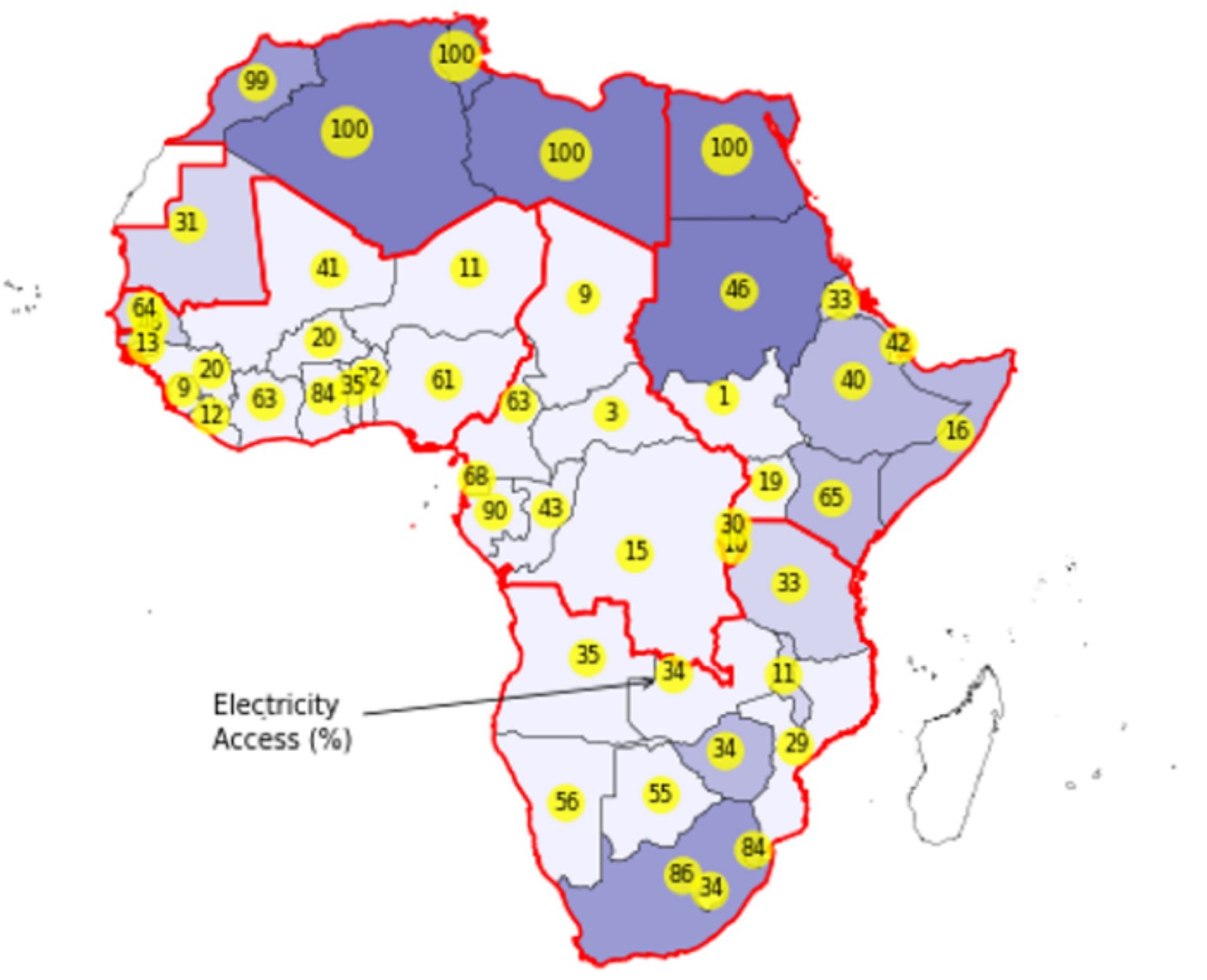

\section{Water Stress Indicator Low $(<10 \%)$ \\ Low medium (10-20\%) \\ Medium high (20-40\%) \\ High (40-80\%) \\ Extremely high $(>80 \%)$}

\section{Figure 1}

Water stress (\%) indicator (2013-2017) and electricity access level (\%) (2016) by country. The level of water stress: freshwater withdrawal as a proportion of available freshwater resources is the ratio between total freshwater withdrawn by major economic sectors and total renewable freshwater resources, after taking into account environmental water requirements 26. Electricity access refers to the percentage of people in a given area that have relatively simple, stable access to electricity. Countries are grouped into power pools shown by the red outline. The list of countries per power pool is shown in Table 1. (Data source: FA027, IEA7, Map created by the authors). Note: The designations employed and the presentation of the material on this map do not imply the expression of any opinion whatsoever on the part of Research Square concerning the legal status of any country, territory, city or area or of its authorities, or concerning the delimitation of its frontiers or boundaries. This map has been provided by the authors. 


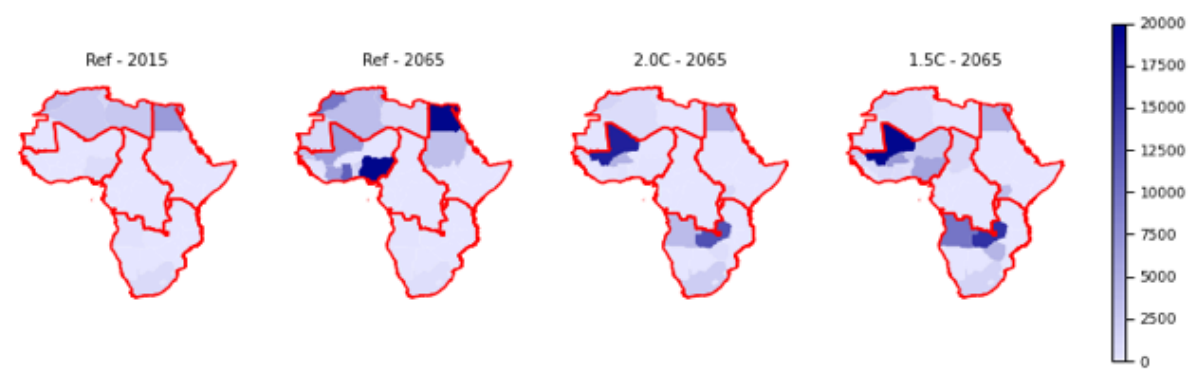

b.

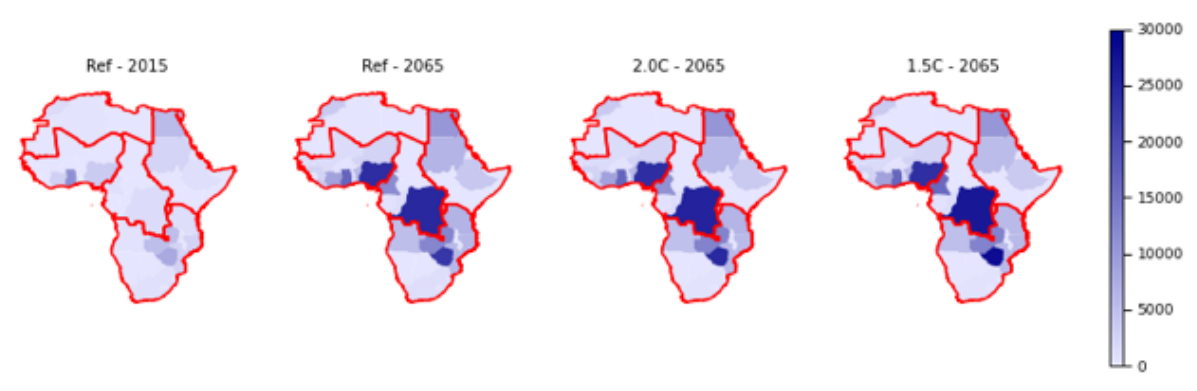

c.

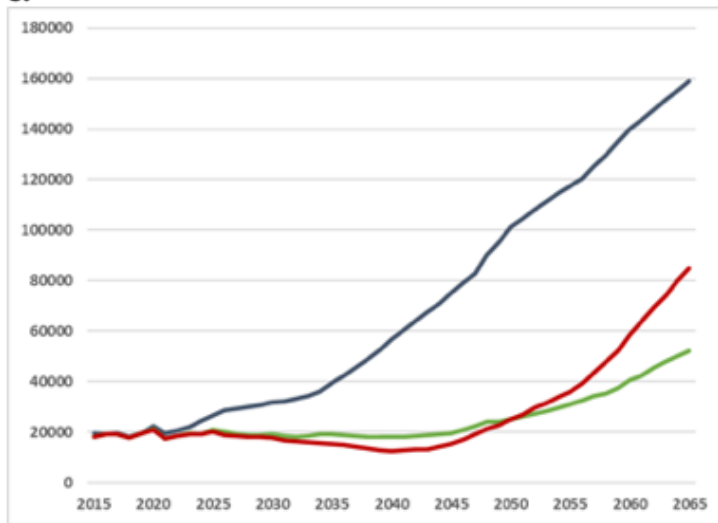

d.

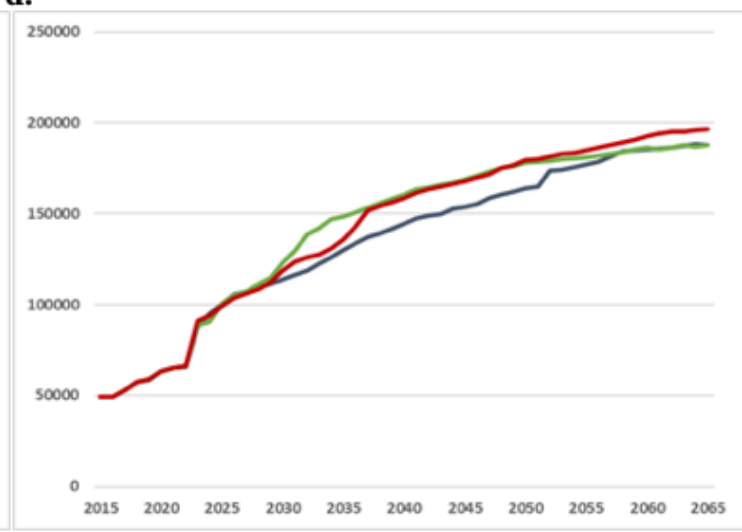

$2.0 \circ \longrightarrow 1.50 \mathrm{C}$

Figure 2

Water withdrawal and consumption in Africa across the scenarios. a. Water withdrawal in a million cubic meters $(\mathrm{mcm})$ across the reference, $2.0^{\circ} \mathrm{C}$ and $1.5^{\circ} \mathrm{C}$ scenarios in 2015 and 2065 . b. Water consumption in mcm across the reference, $2.0^{\circ} \mathrm{C}$ and $1.5^{\circ} \mathrm{C}$ scenarios in 2015 and 2065. Note in the reference scenario in 2065, Egypt attempts to withdraw $\sim 32000 \mathrm{mcm}$ and Nigeria $\sim 72000 \mathrm{mcm}-$ these values are clipped at $20000 \mathrm{mcm}$ on the plot. c. Water withdrawal in mcm at a continental level across the reference, $2.0^{\circ} \mathrm{C}$ and $1.5^{\circ} \mathrm{C}$ scenarios. $\mathrm{d}$. Water consumption in $\mathrm{mcm}$ at a continental level across the reference, $2.0^{\circ} \mathrm{C}$ and $1.5^{\circ} \mathrm{C}$ scenarios. Note: The designations employed and the presentation of the material on this map do not imply the expression of any opinion whatsoever on the part of Research Square concerning the legal status of any country, territory, city or area or of its authorities, or concerning the delimitation of its frontiers or boundaries. This map has been provided by the authors. 
a.

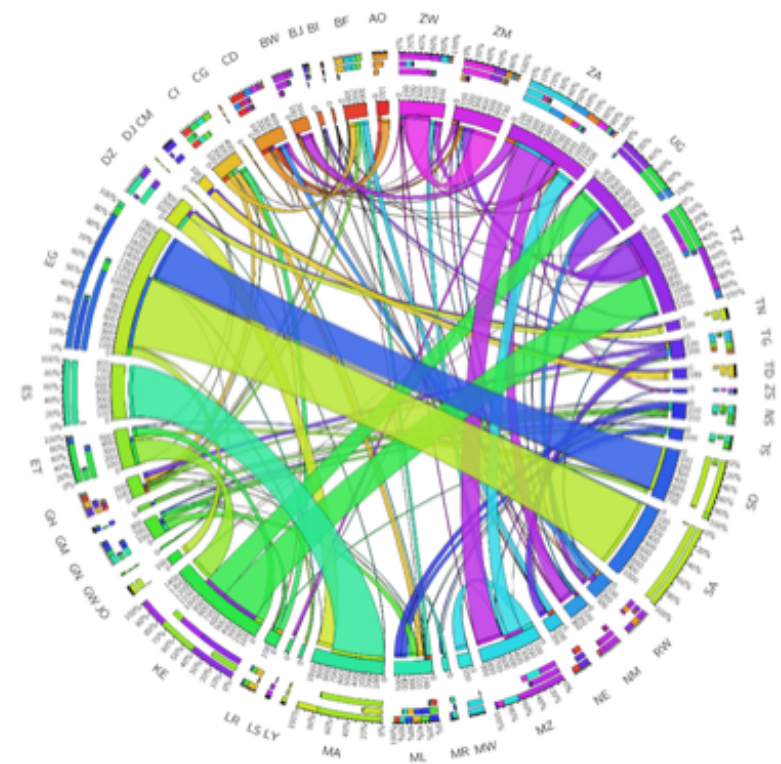

c.

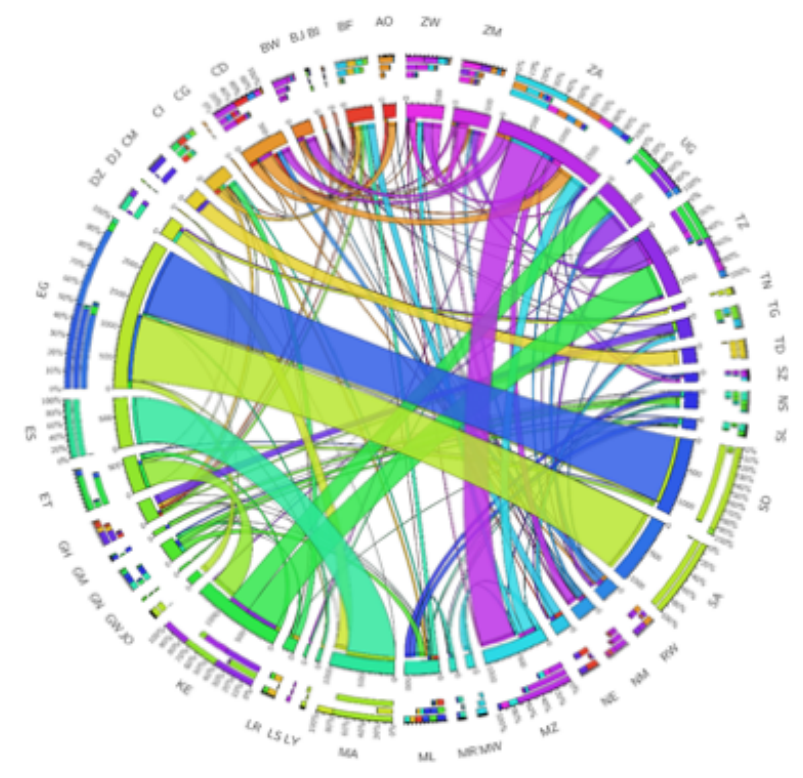

b.

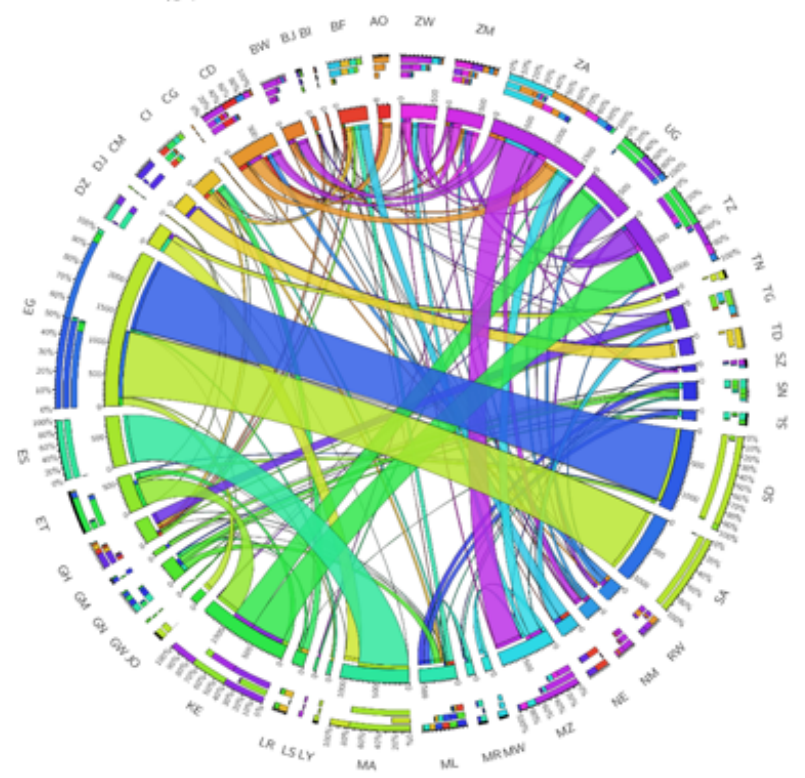

\section{Figure 3}

Cumulative electricity trade (2015-2065) among the African countries in each scenario. a Reference scenario, b 2.0oC scenario, c 1.5oC scenario. The outer circle represents the ISO 3166-1 alpha-228 country code of each African country. The three bars (percentage mix), starting from the outlying to the innermost bar, refer to i) exported electricity, ii) imported electricity, iii) the difference between the exported and imported electricity. The color of the bar (arc), on the inner circle, is specific to the country where electricity is exported or imported from and the scale indicates the absolute values of electricity trade in TWh. Flow bands present the traded electricity among the countries. Flow bands attached to a country's inner circle represent exports from that country and vice-versa. Country codes can be found in Table 1 (ES: Spain, JO: Jordan, SA: Saudi Arabia). 
a.

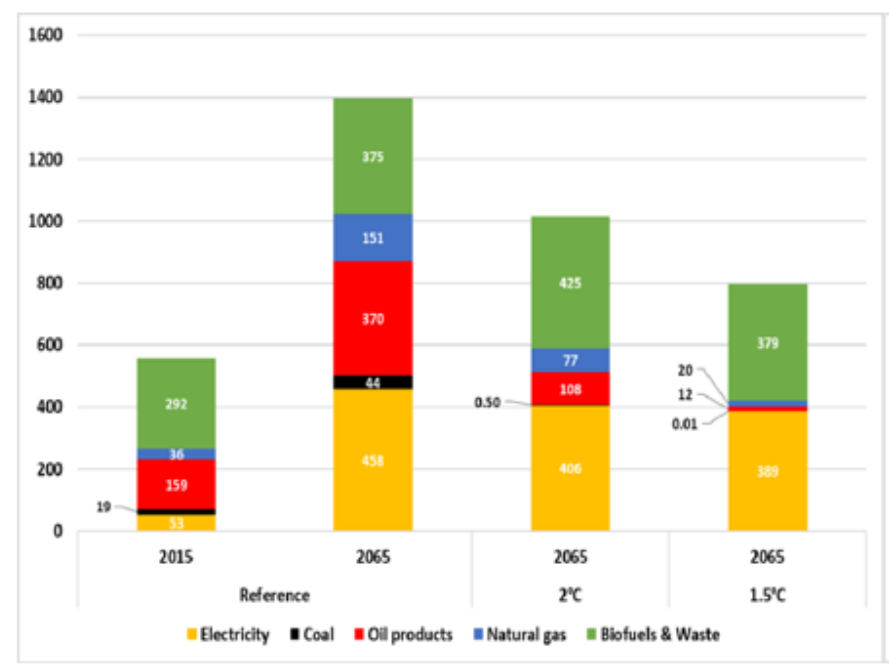

b.

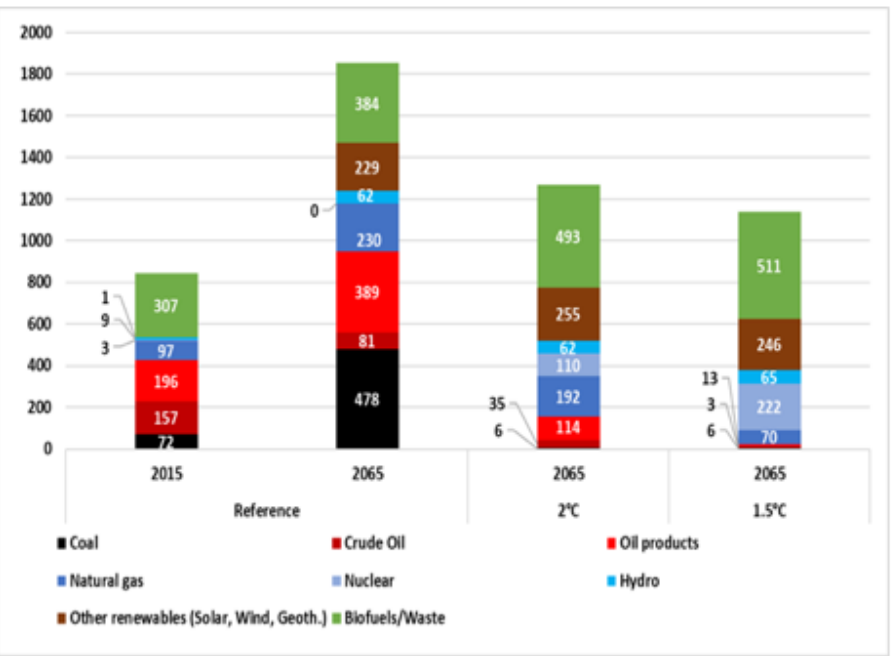

\section{Figure 4}

Total final consumption (Mtoe) and total primary energy supply in Africa across the scenarios. a. Total final consumption (Mtoe) in Africa across the scenarios $(2015,2065)$. b. Total primary energy supply (Mtoe) in Africa across the scenarios $(2015$, 2065).

a.

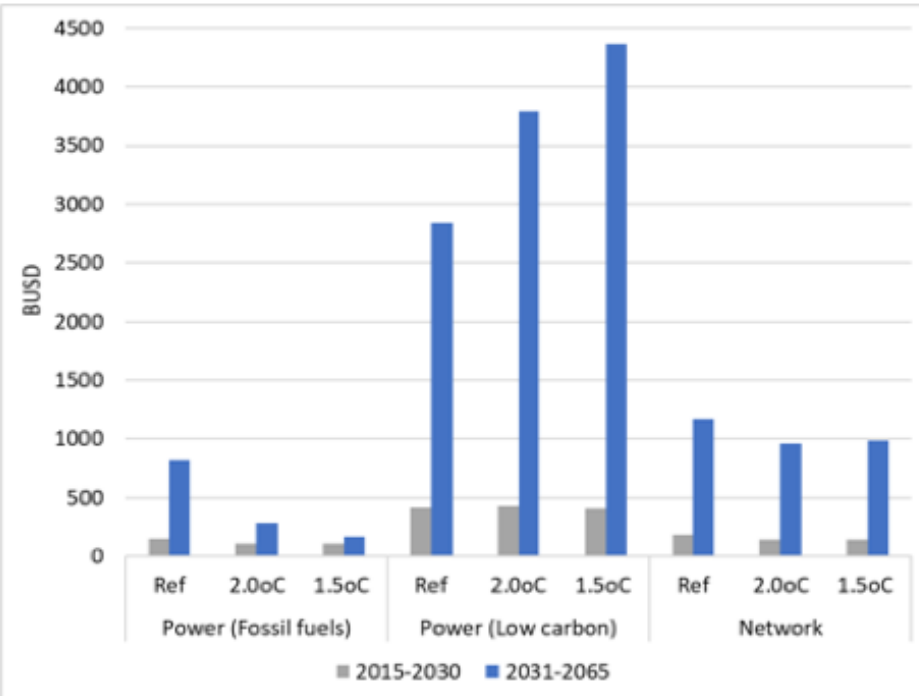

b.

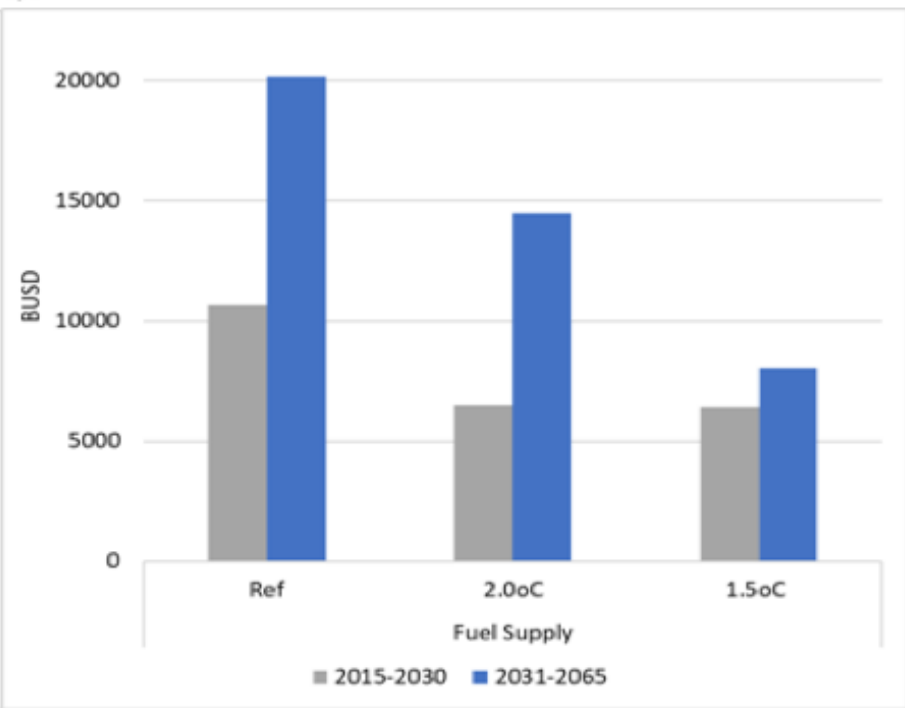

\section{Figure 5}

Comparison of fuel supply costs in the energy sector and capital investment costs in the power sector in Africa among the scenarios. a. Comparison of fuel supply costs in the energy sector in Africa among the scenarios, b. Comparison of capital investment costs in the power sector in Africa among the scenarios.

\section{Supplementary Files}

This is a list of supplementary files associated with this preprint. Click to download. 
- SupplementaryMaterialConflictingobjectivesofenergydevelopmentandwatersecurityinAfrica.docx 